\title{
EFEKTIVITAS RATIONAL EMOTIVE BEHAVIOUR THERAPY UNTUK MENURUNKAN KECEMASAN WANITA YANG MENDERITA KISTA OVARIUM
}

\author{
Dini Darmayanti dan Fuad Nashori \\ Magister Profesi Psikologi, Universitas Islam Indonesia \\ *email: fuadnashori@uii.ac.id
}

\begin{abstract}
Abstrak
Penelitian ini bertujuan untuk menguji efektifitas rational emotive behavior therapy untuk mereduksi tingkat kecemasan pada wanita penderita kista ovarium. Subjek penelitian ini adalah 2 orang wanita yang memiliki kista ovarium, berusia produktif serta memiliki kecemasan sedang atau tinggi. Penelitian ini menggunakan metode Single Case A-B Follow Up. Intervensi yang diberikan pada subjek, yaitu Pelatihan berbasis Rational Emotive Behavior Therapy dan diberikan dalam tiga sesi pertemuan. Pengukuran pada kecemasan menggunakan Taylor Manifest Anxiety Scale (TMAS). Pengukuran dilakukan saat Prates, Pascates dan Tindak lanjut. Hasil penelitian menunjukkan bahwa Rational Emotive Behavior Therapy dapat mereduksi tingkat kecemasan pada kedua subjek dengan adanya perbedaan signifikan antara prates, pascates dan tindak lanjut.
\end{abstract}

Kata kunci: kecemasan, rational emotive behavior therapy, kista ovarium

\section{EFFECTIVENESS OF RATIONAL EMOTIVE BEHAVIOUR THERAPY TO REDUCE THE ANXIETY TO THE WOMEN SUFFERRING FROM OVARIAN CYST}

\begin{abstract}
This study aimed to test the effectiveness of rational emotive behavior therapy on reducing the anxiety level the women with ovarian cyst. Two women with ovarian cyst in the productive age and with the high level and medium level of anxiety were involved as the subject of study. This study used the Single case A-B Follow up method in which. The rational emotive behavior therapy-based training was given as the intervention to subjects within three sessions of meeting. Furthermore, the measurement to anxiety used Taylor Manifest Anxiety Scale (TMAS) conducted in pre-test, post-test and follow up. The results of this study showed that the rational emotive behavior therapy was able to reduce the anxiety among pre-test, posttest and follow up.
\end{abstract}

Keywords: anxiety, rational emotive behavior therapy, ovarian cyst

\section{Pendahuluan}

Kesehatan wanita memiliki dampak besar pada kesehatan dan kesejahteraan generasi penerus di masa yang akan datang. Kesehatan wanita memiliki karakteristik yang sangat unik dan kompleks secara anatomi dan fisiologi, khususnya dalam sistem reproduksi (Berhandus, Loho \& Wantania, 2012). Masalahnya adalah organ reproduksi wanita merupakan salah satu area terjadinya berbagai penyakit, yang disebabkan oleh hormon, kanker, infeksi, mioma atau kista (Apriani, 2015).

Kista ovarium merupakan penyakit khas perempuan yang ditandai oleh adanya pengumpulan cairan yang dibungkus oleh selaput pada indung telur (Imade, 2013). Ada dua jenis tumor yang dapat muncul pada indung telur atau ovarium, yaitu tumor neoplastic dan maligma. Tumor neoplastic 
memiliki karakteristik bersifat jinak serta tidak menyebur ke luar ovarium. Sementara tumor maligma adalah tumor yang bersifat ganas serta bisa menyebar ke berbagai bagian tubuh lain (Lely, 2013). Salah satu masalah terkait penyebaran kista ovarium adalah penyakit ini baru disadari wanita saat kista sudah membesar dan teraba dari luar (Depkes Jawa Tengah, 2015).

World Health Organization atau WHO (2015) mengungkapkan bahwa kasus ovarium terdeteksi paling menonjol berada di negara-negara maju, namun juga banyak terjadi di negara yang sedang berkembang. Di negara-negara maju, rata-rata terdapat 10 orang penderita kista ovarium dari 100.000 orang. Pengecualiannya adalah Jepang di mana rata-rata 6,5 orang dari 100.000 orang. Sementara di negara-negara Amerika Selatin, terdapat 7,7 kasus per 100.000 orang. Berbagai begara berkembang seperti negara-negara di Benua Afrika memiliki kasus kista ovarium yang lebih sedeikit.. Khusus di Indonesia, sebagaimana dilaporkan Kemenkes (2015) terdapat 23.400 orang yang menderita kista dan sebanyak 13.900 orang yang meninggal dunia. Sementara itu, di DIY pada tahun 2016 terdapat 443 orang yang berstatus kunjungan baru dan 443 orang yang berstatus kunjungan lama.

Ada beberapa dampak dari kista ovarium terhadap kehidupan penderitanya. Dampak yang paling ditakutkan adalah gangguan terhadap pembentukan sel telur. Selain itu, dampak yang langsung dirasakan oleh wanita penderita kista ovarium adalah adanya gangguan saat menstruasi, susah buang air kecil, nyeri saat bersenggama, nyeri panggul (Sungkar, 2015).

Hal ini sesuai dengan hasil wawancara kepada salah satu wanita penderita kista ovarium yang bernama AR. Pada tahun 2015, AR saat itu berusia 19 tahun pertama kali mengetahui dirinya memiliki kista dengan ukuran kurang lebih $2,5 \mathrm{~cm}$. AR mengakui bahwa dirinya mengalami berbagai macam keluhan setiap menstruasi. Salah satunya jadwal menstruasi yang tidak teratur. Saat mendengar diagnosis dari dokter, perasaan AR sedih, takut dan gelisah karena AR merasa seseorang yang memiliki kista akan sulit memiliki keturunan. Selang satu tahun kemudian, AR memeriksa diri lagi ke dokter, dan ternyata ukuran kistanya berkembang menjadi $6,8 \mathrm{~cm}$. AR mengakui, sejak didiagnosis, dirinya merasa cukup stres memikirkan penyakitnya dan pola makan tidak dijaga dengan baik. Dokter menyarankan AR untuk melakukan tindakan operasi. Perasaan AR, ketika mengetahui hal tersebut, semakin sedih, takut dan merasa dirinya tidak akan bisa membahagiakan calon pasangannya ketika berumah tangga. Bahkan, keluarga pacar AR mengetahui tentang penyakit tersebut dan menganggap penyakit kista akan mengalami kesulitan mendapat keturunan. Hal ini berdampak pada perilaku AR, salah satunya yaitu mengurangi intensitas pertemuannya dengan keluarga pacar.

Hasil wawancara dari responden di atas menunjukkan bahwa individu yang memiliki penyakit kista ovarium mengalami perasaan takut, stres dan cemas yang diakibatkan pikiran-pikiran atau keyakinan irasional dari diri sendiri maupun lingkungan luar terkait salah satu dampak dari penyakit ini yaitu mengalami gangguan infertilitas. Hal ini memunculkan perilaku tidak nyaman ketika bertemu dengan orang-oramg yang mengetahui bahwa dirinya memiliki penyakit kista ovarium.

Kecemasan yang ada dalam diri seseorang dalam menyikapi penyakit yang datang sesungguhnya merupakan sesuatu yang normal. Ketika seorang wanita mengetahui bahwa dirinya mengalami penyakit pada bagian ovariumnya, sangat mungkin mereka merasakan adanya ketakutan dan ketegangan. Kekhawatiran ini menjadikan mereka berpikir bahwa kematian ini mungkin sudah dekat.

Perasaan cemas yang dialami individu melibatkan reaksi sensional (Atkinson dkk, 2009). Hal ini juga sependapat dengan Corner (Videbeck, 2008) yang menjelaskan bahwa seseorang yang mengalami kecemasan memiliki perasaan takut yang seringkali tidak jelas serta tidak mendapat dukungan yang 
memadai dari situasi yang terjadi. Saat mengalami kecemasan, individu merasa takut, tidak nyaman. Sebagian bahkan mengungkapkan adanya firasat buruk akan ditimpa malapetaka padahal mereka tidak tahu mengapa emosi yang mengancam tersebut terjadi.

Selain itu Buchanan, Milroy, Baker, Thompson dan Levack (2010) juga menjelaskan kecemasan dan kekhawatiran berlebihan dapat berdampak yang signifikan dalam kehidupan dan tanda yang paling jelas terlihat yaitu adanya kegelisahan. Dikatakan oleh Ormrod (2004), bahwa ada empat aspek yang menunjukkan kecemasan, yaitu aspek kognitif, afektif, fisiologis, dan perilaku. Aspek kognitif terkait dengan pikiran negatif, pikiran yang menakutkan, dan berbagai kekhawatiran. Selanjutnya aspek afektif ditandai oleh adanya perasaan tegang. Aspek fisiologis dapat diketahui dari peningkatan denyut jantung, pernafasan, tekanan darah, serta fisiologis lainnya. Terakhir, aspek perilaku diketahui dari perilaku gelisah dan berjalan mondar-mandir (Greenberg, 2002).

Kecemasan yang dialami oleh individu dapat direduksi melalui berbagai upaya, beberapa di antaranya adalah terapi kognitif perilaku religius, intervensi kelompok dan koping religi. Penelitian Irawati, Subandi, Kumolohadi (2011) melakukan pemberian terapi kognitif perilaku religius untuk menurunkan kecemasan terhadap kematian pada penderita HIV/AIDS sehingga mudah diterapkan oleh subjek. Hasil penelitian ini menunjukkan adanya perbedaan yang signifikan antara kelompok control dengan kelompok eksperimen. Penelitian ini memiliki kelemahan, yaitu tidak semua responden mengikuti teknik yang diberikan dengan baik karena pengaruh tingkat keseriusan responden.

Penelitian lainnya dilakukan oleh Putri (2012). Penelitian ini menunjukkan bahwa intervensi kelompok pada lansia dapat membantu mengurangi kecemasannya. Teknik ini mengontrol dari sisi kognitif, perilaku dan respon fisiologis yang dirasakan jauh kebih sehat dari sebelumnya. Namun, penelitian ini memiliki kelemahan seperti kurangnya pemberian tugas-tugas tertulis, mengingat usia partisipan yang sudah lanjut dan mengalami kesulitan menggerakkan otot mereka yang berhubungan dengan alat tulis.

Selanjutnya penelitian dari Amita (2016) menunjukkan bahwa pelatihan koping religius dapat menurunkan kecemasan pada penderita kista ovarium. Pelatihan ini mengajarkan para penderita untuk mengenali pikiran serta perasaan yang dimiliki serta pengendalian diri, pemahaman tentang dzikir dan mensyukuri nikmat Allah SWT. Penelitian ini memiliki kelemahan yaitu dalam pencarian subjek terbatas karena ijin penelitian di rumah sakit yang ada di Yogyakarta.

Berdasarkan penjelasan di atas maka wanita dengan kista ovarium memiliki dampak yang cukup mengganggu bagi penderitanya sehingga mengalami kecemasan dalam dirinya sehingga tidak mengetahui cara mengatasinya. Berdasarkan hal di atas maka sangat dibutuhkan penanganan yang tepat untuk meminimalisasi kecemasan dengan Rational Emotive Behaviour Therapy. Nelson-Jones (2011) menyatakan bahwa Rational Emotive Behaviour Therapy menekankan bahwa perilaku bermasalah pada diri individu disebabkan oleh pemikiran yang irasional. REBT difungsikan para ahli psikologi untuk mengajar klien agar mampu memahami dan mempergunakan keyakinan rasional untuk meminimalisasi penderitaan klien.

Penelitian dari Faizah (2018) membuktikan terapi kognitif emotif perilaku dapat menurunkan kecemasan pada penderita Extrapiramidal Sindrom mahasiswa. REBT ini dimaksudkan untuk menyelesaikan gangguan emosional diri individu seperti cemas, benci, takut, rasa bersalah dan marah yang mengakibatkan individu berpikir irasional dan melatih individu agar mampu menghadapi kenyataan hidup secara rasional dan membangkitkan kepercayaan diri dan kemampuan diri. Dalam penelitian ini, perlakuan yang digunakan adalah pelatihan berbasis REBT. Peneliti memilih REBT karena 
TEBT ini dapat diterapkan pada individu yang memiliki kecemasan, perilaku adiktif, obsesif-kompulsif dan gangguan stress pasca-trauma (Ellis, 2001). Selain itu, pelatihan ini efektif menghasilkan penurunan gejala yang cepat dan perubahan besar untuk klien (Seligmen \& Reinchenberg, 2013).

Berdasarkan uraian di atas, dapat dirumuskan tujuan penelitian ini, yaitu mengetahui efektivitas Rational Emotive Behaviour Therapy untuk mereduksi kecemasan pada penderita kista ovarium.

\section{Metode penelitian}

\section{Desain Penelitian}

Variabel tergantung pada penelitian ini adalah kecemasan dan variabel bebasnya, adalah Rational Emotive Behavior Therapy. Penelitian ini menggunakan rancangan reversal desain A-B-Follow Up (Barlow \& Hersen, dalam Sunanto, 2005). Desain A-B merupakan desain dasar dari penelitian eksperimen tunggal (Sunanto, 2005). Prosedur utama yang ditempuh dalam desain A-B-Follow Up meliputi pengukuran kondisi target pada fase baseline dan kemudian diberikan intervensi. Selama fase intervensi kondisi subjek secara kontinyu dilakukan pengukuran (Loovas, dalam Sunanto 2005), kemudian dilakukan Follow Up.

Tabel 1. Rancangan Penelitian

\begin{tabular}{|c|c|c|c|}
\hline Prates & Perlakuan & Pascates & Follow up \\
\hline 01 & $x$ & $\mathrm{O} 2$ & 03 \\
\hline \multicolumn{4}{|l|}{ Keterangan : } \\
\hline Prates & \multicolumn{3}{|c|}{ : Pengukuran sebelum dilakukan intervensi } \\
\hline$x$ & \multicolumn{3}{|c|}{ : Perlakuan dalam bentuk REBT } \\
\hline Pascates & \multicolumn{3}{|c|}{ : Pengukuran setelah intervensi } \\
\hline Follow Up & \multicolumn{3}{|c|}{ : Pengukuran dua pekan setelah pascates } \\
\hline
\end{tabular}

\section{Subjek Penelitian}

Subjek penelitian diambil dengan menggunakan teknik Purposive Sampling, yaitu pengambilan sampel berdasarkan pertimbangan peneliti (Sugiyono, 2011). Subjek penelitian ini berjumlah 2 orang, dengan kriteria sebagai berikut: (a) Wanita, (b) Usia Produktif, (c-) Mengidap Kista Ovarium, (d) Berpendidikan minimal SMA, dan (e) Memiliki kecemasan yang tinggi atau sedang.

\section{Alat Ukur}

Pengumpulan data ini dilakukan melalui metode skala psikologi, observasi dan wawancara. Variabel kecemasan diukur dengan skala TMAS (Taylor, 2000) yang disesuaikan dengan keadaan kecemasan pada penderita kista endometriosis. Skala TMAS memiliki 50 item pernyataan untuk mengukur aspek fisiologis, intelektual dan emosional. Pengukuran skala kecemasan ini meminta responden untuk memilih pernyataan yang menggambarkan kecenderungan mengalami kecemasan yang ditandai dengan jawaban "ya" dan "tidak". Subjek diminta memilih satu jawaban yang sesuai dengan keadaan dirinya pada setiap aitem. Pada pernyataan Favorable, subjek akan mendapat nilai 1 apabila menjawab "ya" dan mendapat nilai 0 bila menjawab "tidak" pada pernyataan Unfavorable. Skala TMAS ini memiliki butir item yang sahih. Item ini memiliki koefisien validitas instrumen terentang 
antara 0,535 sampai dengan 0,921 pada taraf kepercayaan 95\%. Hasil perhitungan menunjukkan semua item memiliki validitas lebih besar 0,05 dengan kata lain dinyatakan valid. Sementara koefisien reliabilitas TMAS adalah 0,881 artinya memiliki tingkat konsistensi tinggi (Arismawati,2016).

\section{Prosedur Intervensi}

Intervensi yang digunakan dalam penilitian ini adalah adalah Rational Emotive Behavior Therapy. Terapi ini mengajarkan dan membantu subjek bagaimana melawan keyakinan irasional sehingga dampak dari keyakinan dan perasaan yang diakibatkan kecemasan dapat diubah menjadi rasional dengan tujuan memberikan dampak positif baik sisi emosional, intelektual dan fisiologis dengan memberikan beberapa tahapan pelatihan dan tugas rumah sesuai target yang ingin dicapai. Rational emotive behavior therapy memiliki tujuan untuk mengubah dan memperbaiki sikap, persepsi, keyakinan, cara berpikir, serta pemikiran-pemikiran yang tidak masuk akal menjai pandangan yang dapat masuk akal. Dengan begitu, individu dapat mengembangan potensi diri, meningkatkan aktualisasi diri sekaligus menghilangemosi-emosi negative yang tidak sehat.

Berangkat dari pemikiran bahwa manusia merupakan harmoni dari aspek-aspek kognitif, emosi, dan perilaku, Ellis (Dryden, 2009) mengembangkan beberapa Teknik dalam REBT, yaitu teknik kognitif, teknik emotif, dan Teknik perilaku. Teknik pertama adalah Teknik kognitif yang dilakukan dengan disputing irrational beliefs (menentang keyakinan irasional). Disputing meliputi detecting, debating, dan discriminating. (a) Detecting berisi mencari adanya keyakinan irasional, seperti "Hanya boleh...", "Hanya bisa..." dan lainnya. Keyakinan seperti itu berdampak buruk pada emosi dan perilaku subjek. (b) Debating dilakukan dengan memberikan beberapa pertanyaan kepada subjek yang bersifat mengarahkan subjek untuk menuju pikiran yang lebih rasional. (c) Discriminating yang dilakukan untuk membantu subjek memisahkan antara keinginan atau hasrat (nonabsolute value) dengan kebutuhan (absolute value), sehingga dengan demikian subjek lebih bijak dalam menentukan pilihan dalam hidupnya.

Kedua adalah Teknik Emotif. Teknik yang digunakan pada terapi ini adalah guided imagery. Teknik ini dilakukan dengan tujuan untuk melatih subjek mengendalikan emosi negatif atau perasaan yang tidak menyenangkan. Ketiga adalah Teknik Perilaku. Teknik perilaku diberikan dengan memberikan Homework dan paspor perubahan untuk melatih subjek berani mengambil tindakan untuk mencapai perubahan yang diinginkan.

Terapi ini akan didasarkan kepada Rational Emotive Behavior Therapy yang dilakukan oleh Siburian, Karyono, dan Dian (2010). REBT dilakukan dengan tiga kali pertemuan dan setiap pertemuan terdiri atas 8 sesi. Setiap sesi dibutuhkan waktu sekitar kurang lebih 30 menit dengan total keseluruhan 240 menit. Sebelum dan sesudah pemberian intervensi, peserta akan diukur kecemasannya dengan skala TMAS. Hal ini bertujuan agar terlihat perbedaan skor kecemasan sebelum dan sesudah diberikan perlakuan.

\section{Teknik Analisis Data}

Teknik analisis data yang digunakan dalam penelitian ini adalah teknik analisis data kualitatif dan kuantitatif. Teknik analisis kuantitatif menggunakan perangkat lunak Statistical Product and Services Solution (SPSS) versi 16.0 for windows. Pengujian hipotesis dalam penelitian menggunakan paired sample t-test. Analisis ini digunakan untuk membandingkan hasil dari subjek yang sama dengan 
keadaan yang berbeda. Kemudian dilihat dari hasil perubahan skor saat prates, pasca intervensi dan follow-up (tindak lanjut). Sementara itu, analisis kualitatif dilakukan pula analisis berupa observasi, wawancara dan lembar tugas.

\section{Hasil Penelitian}

\section{Analisis Kuantitatif dan Analisis Kualitatif}

Berdasarkan intervensi yang dilakukan pada subjek, riset tentang intervensi ini menggunakan analisis kuantitatif dan kualitatif dan dilakukan dengan melihat skor skala dari TMAS mulai prates, pascates dan tindak lanjut (Follow Up).

Tabel 2. Deskripsi Data Penelitian Skor Kecemasan

\begin{tabular}{cccc}
\hline \multirow{2}{*}{ Nama } & \multicolumn{3}{c}{ Pengukuran } \\
\cline { 2 - 4 } & Prates & Pascates & Tindak Lanjut \\
\hline Subjek 1 (A) & 35 & 22 & 15 \\
Subjek 2 (M) & 28 & 16 & 10 \\
\hline
\end{tabular}

Berdasarkan tabel tersebut, maka dapat dilihat bahwa skor subjek $\mathrm{A}$ dan $\mathrm{M}$ mengalami penurunan. Subjek A sebelum mengikuti pelatihan terlihat total skor 35 , sedangkan pada subjek $M$ memiliki skor 28. Pada saat mengikuti pelatihan, dilakukan pengukuran kembali. Terlihat pada subjek A mengalami penurunan kecemasan dengan skor 22 dan subjek $M$ skor 16 . Setelah melakukan pelatihan, kembali dilakukan pengukuran lanjut saat tindak lanjut, yaitu subjek A dengan skor 15 dan subjek M skor 10. Jika digambarkan melalui grafik, maka kondisi kedua subjek adalah sebagai berikut:

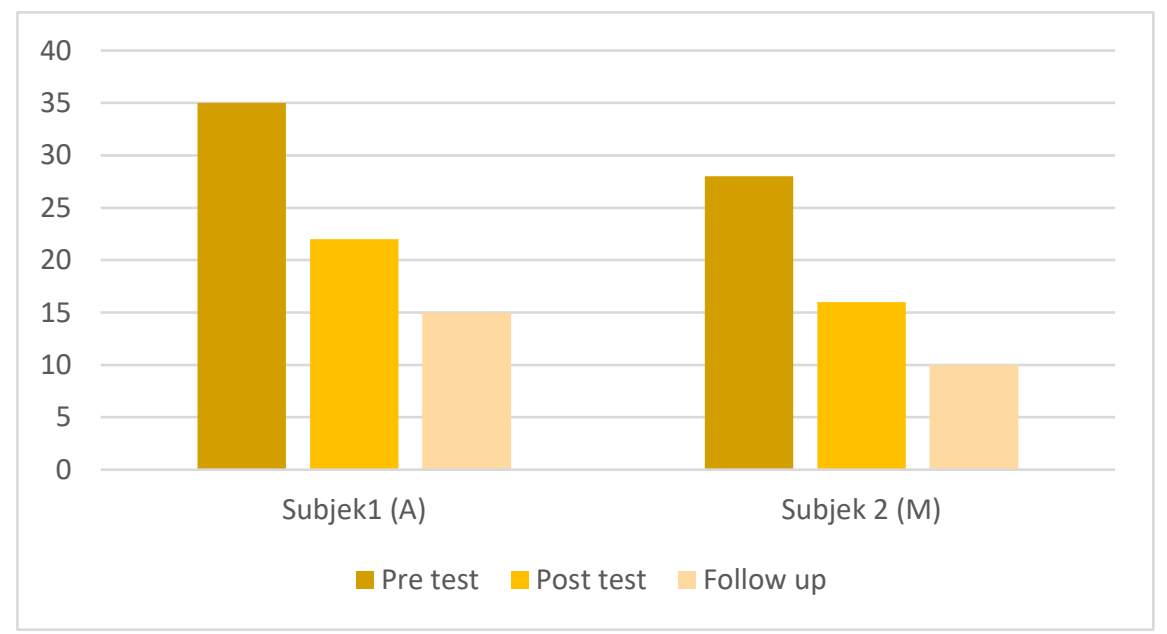

Gambar 1. Data Subjek

Secara keseluruhan, seperti yang terlihat pada histogram menunjukkan adanya penurunan tingkat kecemasan para subjek dari sebelum diberikan pelatihan berbasis rational emotive behaviour therapy dan sesudah diberikan pelatihan berbasis. Ini membuktikan bahwa terapi ini efektif bagi para subjek. 
Analisis pendukung lainnya yaitu dengan analisis kualitatif yang bertujuan untuk mengetahui pengalaman subjek dalam mengikuti masing-masing sesi terapi serta perkembangan kemajuan subjek dari awal hingga akhir penelitian akan diuraikan berikut ini.

Subjek 1 (A). A merupakan wanita berusia 22 tahun dan memiliki postur tubuh tinggi dan proposional. Berdasarkan hasil pengisian skala kecemasan sebelum pelaksanaan rational emotive behaviour (prates) diketahui hasil kecemasan A berada kategori tinggi dengan jumlah skor sebesar 28. Subjek A belum menikah dan baru lulus kuliah. A mengaku dirinya sering merasakan nyeri pada perut bagian bawah hinga area punggung bawah setiap menjelang menstruasi. A merasakan ketidaknyamanan tersebut bertahun-tahun dan memeriksakan diri ke dokter bersama ibunya. Pada tahun 2016, A didiagnosis kista ovarium dengan ukuran kista sebesar $6,5 \mathrm{~cm}$. A disarankan oleh dokter untuk segera dioperasi menghindari resiko yang lebih besar, salah satunya yaitu kista akan pecah jika dibiarkan. A mengakui dirinya gampang cemas sejak didiagnosis.

Semakin hari, A mulai sulit tidur nyenyak, cemas dengan stigma penderita kista akan mengalami infertilitas, dan perasaan sedih (lembar kerja 1). A mengikuti rational emotive behaviour therapy selama tiga kali pertemuan dan datang tepat waktu. A sangat kooperatif dalam setiap sesi pelatihan dan aktif tanya jawab. Hasil isian lembar kerja 2 dan 3 menunjukkan pikiran-pikiran irasional dan muncul emosi negatif. Tingkat SUD pada lembar kerja 2 dan 3 memiliki skor tinggi hingga sedang. Selanjutnya pada lembar kerja 4 didapatkan tingkat SUD turun menjadi rendah dan sangat rendah. Perubahan pemikiran irasional menjadi rasional berdampak positif pada emosi $A$.

Pada pertemuan ketiga, A diberikan lembar kerja 5 yang berisi target perubahan yang ingin dicapai untuk mengurangi rasa cemasnya selama satu minggu. Di lembar kerja 5 , target perubahan yang didapat semakin meningkat ke arah berhasil dan sangat berhasil. Hal ini menunjukkan bahwa adanya perubahan positif selama mengikuti sesi pelatihan. Sesi tindak lanjut, A mengungkapkan bahwa pelatihan yang diberikan sangat bermanfaat untuk dirinya. A selalu mempraktekan apa yang telah ilmu yang didapatkan dalam kesehariannya. Selain itu, A merasa dirinya jauh lebih positif dan berhasil mendapat pekerjaan yang diinginkan.

Berikut ini adalah grafik prates, pascates, dan tindak lanjut dari A:

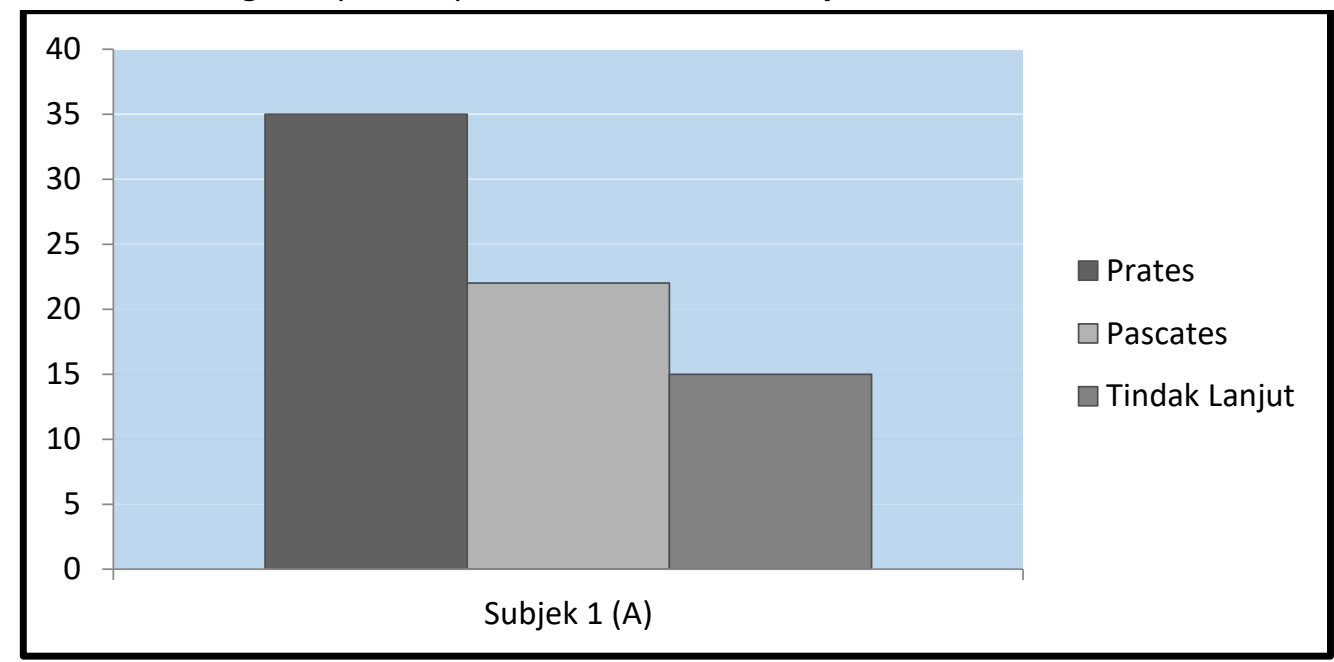

Gambar 2. Skor kecemasan Subjek (A) pada saat prates, pascates dan Follow Up 
A merupakan subjek yang bersemangat untuk mengikuti rational emotive behaviour therapy dari awal pertemuan hingga akhir. A mengerjakan semua lembar kerja dengan baik dan sangat kooperatif selama berkomunikasi. Pada saat tindak lanjut, A menjelaskan bahwa tingkat kesadaran terhadap kista sangat baik. Hal yang disadarinya yaitu jika dirinya cemas maka kista akan berkembang. Begitu sebaliknya, jika dirinya positif, maka kista akan semakin mengecil. Selain itu, dukungan dan motivasi dari keluarga serta kerabat dekat menciptakan situasi yang baik sehingga memberikan hasil optimal.

Subjek 2 (M). Subjek M berusia 18 tahun dan saat ini duduk di kelas XII (akhir semester). M didagnosa kista ovarium ketika M duduk dikelas 8 (setara kelas dua SMP) dengan ukuran kista 5,6 cm. $M$ diajak oleh ibunya untuk memeriksakan diri ke dokter setelah mengeluhkan rasa sakit yang luar biasa menjelang menstruasi hingga menstruasi hari pertama. M mengakui awal didiagnosis memiliki kista ovarium, M tidak mengerti dengan penyakit tersebut. Semakin bertambah usia, M lebih memahami tentang kista ovarium serta dampaknya. M merasa cemas saat mengetahui salah satu resiko memiliki kista ovarium yaitu mengalami infertilitas. $M$ merasa pusing setiap memikirkan hal tersebut dan pola makan tidak teratur. Saat ini $M$ tidak melanjutkan untuk pengobatan atau pemeriksaan kembali karena ia tidak ingin mendengar informasi yang tidak sesuai harapan yang akan mempengaruhi emosi $\mathrm{M}$.

Berdasarkan hasil pengisian skala kecemasan (prates) diketahui bahwa skor M termasuk kategori sedang dengan nilai 23. Pada lembar kerja ke 2, M menuliskan dirinya pesimis jika tidak bisa menyelesaikan masalah terutama mengenai kistanya, sehingga membuat M mudah kesal dan sedih. Pada lembar kerja ke 4, M mampu mengubah pemikiran irasional tentang dirinya menjadi rasional dan mengubah emosi menjadi positif. Selanjutnya, M diberikan tugas pada lembar 5 mengenai target perubahan yang ingin dicapai salah satunya, lebih bersabar dan tenang dalam menyikapi suatu kejadian dengan skor SUD 2 (rendah) dan di akhir pencapaian menjadi 9 (tinggi).

Selama mengikuti pelatihan dari awal hingga akhir, $M$ cukup kooperatif walaupun harus diberikan motivasi dalam membuat lembar tugas yang diberikan fasilitator. Pada sesi tindak lanjut, $M$ mengungkapkan dirinya sering melakukan self-talk karena memberikan energi dan emosi yang positif. Berikut ini adalah grafik prates, pascates dan tindak lanjut dari M.

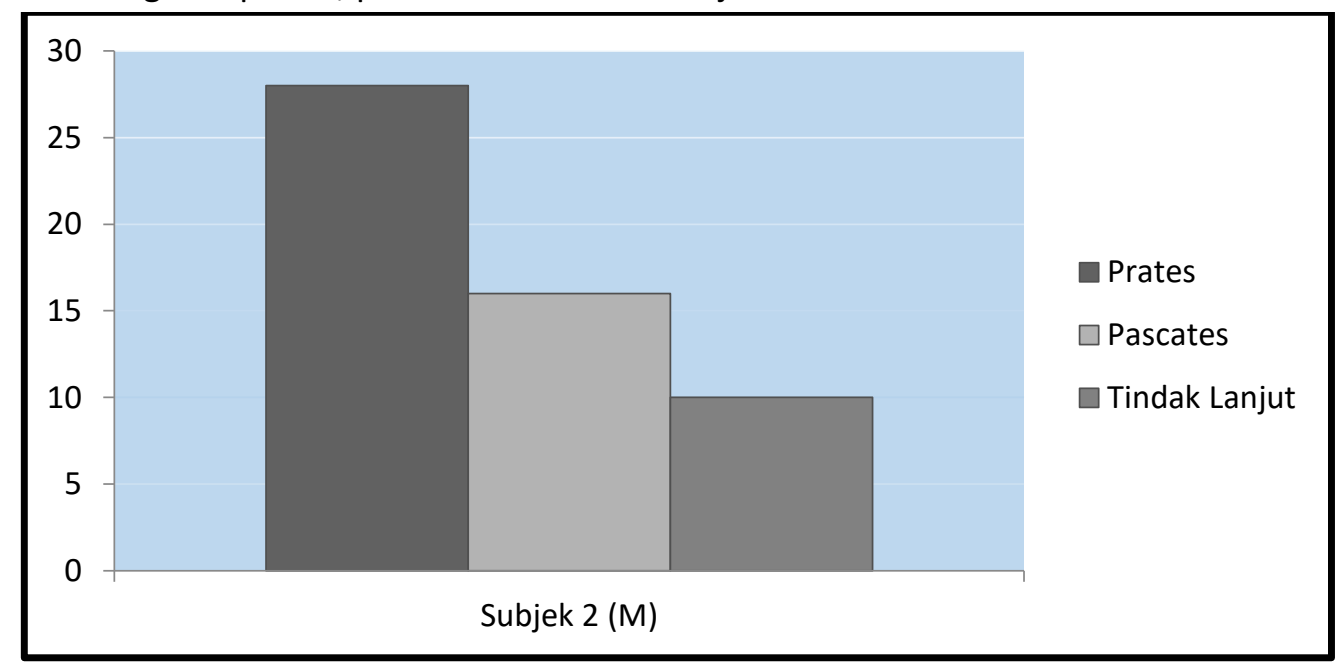

Grafik 3. Skor kecemasan Subjek (M) pada saat prates, pascates dan Follow Up 
Dapat dilihat skor $\mathrm{M}$ dari ketiga pengukuran menunjukkan adanya perubahan pada tingkat kecemasannya. Skor awal yang diperoleh yaitu 28 pada kategori sedang dan menurun pada skor 10 yang berarti rendah. Hal ini dipengaruhi oleh subjek yang selalu rutin menerapkan teknik self-talk dalam kesehariannya sehingga $\mathrm{M}$ menjadi rasional.

\section{Hasil Uji Hipotesis}

Berdasarkan uji asumsi yang telah dilakukan yaitu uji normalitas menunjukkan terdistribusi dengan normal, maka hal ini memenuhi syarat untuk dilakukan uji hipotesis menggunakan uji statistic dengan uji t atau paired sample t-test. Hipotesis penelitian ini yaitu adanya pengaruh efektifitas Rational Emotive Behavior Therapy dalam menurunkan kecemasan pada wanita penderia kista ovarium. Hasil analisis data dengan uji $t$ dapat dilihat pada table berikut:

Tabel 3. Rangkuman uji t Prates-Pascates, Pascates-Follow up, dan Prates-Tindak Lanjut

\begin{tabular}{cccc}
\hline Keterangan & $\mathbf{t}$ & $\mathbf{p}$ & Keterangan \\
\hline Prates-Pascates & 25,00 & 0,025 & signifikan \\
Pascates-Tindak lanjut & 15,00 & 0,042 & signifikan \\
Prates-Tindak lanjut & 19,00 & 0,033 & signifikan \\
\hline
\end{tabular}

Hasil uji hipotesis pada tabel 3 menunjukkan adanya nilai signifikansi (p) sebesar 0,025 $(p<0,05)$ sehingga menunjukkan adanya perbedaan yang signifikan antara prates (sebelum pelatihan) dengan pascates (setelah pelatihan) terhadap tingkat kecemasan pada wanita yang memiliki kista ovarium. Selanjutnya, terdapat juga perbedaan yang signifikan antara pascates (setelah pelatihan) dan tindak lanjut sebesar 0,042 $(p<0,05)$. Kemudian pada tabel 3 dapat dilihat adanya nilai signifikansi $(p)$ sebesar $0,033(p<0,005)$ sehingga ada perbedaan signifikan antara skor prates (sebelum pelatihan) dengan tindak lanjut pada tingkat kecemasan kedua subjek.

\section{Pembahasan}

Penelitian ini bertujuan untuk mengetahui efektivitas rational emotive behaviour therapy untuk menurunkan tingkat kecemasan pada wanita penderita kista ovarium. Pengukuran ini dilakukan saat sebelum, sesudah dan periode tindak lanjut pada dua orang subjek. Berdasarkan pada analisis kuantitatif dengan menggunakan uji paired sample t-test, diketahui bahwa ada perbedaan yang signifikan tingkat kecemasan antara pascates dan tindak lanjut pada kedua subjek. Berdasarkan penjelasan tersebut, dapat disimpulkan bahwa pelatihan berbasis Ratinonal Emotive Behavior Therapy memiliki pengaruh terhadap menurunnya tingkat kecemasan pada wanita penderita kista ovarium.

Rational emotive behavior therapy terdiri atas materi psikoedukasi mengenai kecemasan, mengenal keyakinan irasional, mengubah keyakinan irasional, menyangkal keyakinan irasional, membuat target perubahan serta melakukan sesi Guided Imagery dan Self Talk. Keterampilan yang diajarkan dalam pelatihan ini adalah mengenal keyakinan diri sendiri. Berdasarkan penelitian Siburian (2010), diketahui bahwa mengenal keyakinan diri sendiri pada subjek akan menentukan keyakinan yang mendasari subjek sehingga mampu membedakan antara irasional dan rasional. Selama proses berlangsung, kedua subjek mengidentifikasi sendiri apakah keyakinan mereka masuk pada irasional atau rasional. Kedua subjek menyadari bahwa keyakinan mereka merupakan keyakinan yang 
irasioanal. Selanjutnya, subjek mengidentifikasi kembali dampak pada perasaan melalui lembar kerja evaluasi mengenal keyakinan irasional dan perasaan yang muncul dengan keyakinan tersebut.

Tahapan pelatihan berikutnya, subjek akan diberikan teknik menyangkal untuk mengubah keyakinan menjadi rasional. Penyangkalan keyakinan irasional ini didampingi oleh fasilitator dengan memberikan pertanyaan-pertanyaan kelogisan serta bukti dari keyakinan subjek. Menurut Drydren (2009), penentangan atau penyangkalan membantu subjek mendefinisian pernyataan-pernyataan secara lebih rasional. Selanjutnya, fasilitator dan subjek akan menyepakati keyakinan yang lebih rasional untuk mencapai perasaan dan konsekuensi yang diinginkan.

Subjek penelitian ini juga mempraktikkan teknik untuk menyangkal keyakinan irasional yang memunculkan kecemasan, emosi negatif serta membantu subjek menerima dan menghadapi kehidupan dengan latihan Guided Imagery. Seligman dan Reichenberg (2013) menyatakan teknik ini membantu subjek mengubah emosi-emosinya dari tidak sehat menjadi sehat dengan bantuan konselor professional. Subjek perlu mengulangi langkah ini satu sampai tiga kali paling tidak minimal 10 menit sampai subjek tidak mengalami emosi-emosi yang tidak sehat. Hal ini sesuai dengan yang diungkapkan oleh subjek $\mathrm{A}$ dan $\mathrm{M}$ pada pertemuan tindak lanjut (Follow-up) bahwa kedua subjek merasakan manfaatnya yaitu memberikan efek tenang, dapat berpikir lebih jernih dan rasional sehingga muncul emosi positif.

Selain itu, kedua subjek penelitian diberikan materi mengenai Self-Talk. Keterampilam ini dilakukan untuk membantu menyangkal keyakinan yang tidak masuk akal dan mengembangkan pemikiran yang lebih sehat, yang akan menghasilkan self-talk lebih positif (Erford, 2016). Menurut Pearson (2000), tipe Self-Talk sangat dianjurkan untuk subjek atau klien di mana perasaan pesimisme dan kecemasan lebih mendominasi. Self-Talk akan memunculkan perasaan atau perilaku yang positif. Hal ini sesuai dengan kondisi subjek penelitian setelah melakukan teknik self-talk, di mana subjek $A$ merasa ia menjalani hari-harinya lebih optimis dan rasa cemas pada dirinya jauh lebih berkurang. Pernyataan serupa juga diungkapkan oleh subjek $\mathrm{M}$, keyakinan irasionalnya berubah menjadi rasional baik terkait sakit yang dideritanya maupun dihadapkan dengan kondisi yang tidak diharapkannya. Pelatihan selanjutnya yaitu subjek diberikan tugas rumah sebagai bahan evaluasi target pencapaian yang ingin dicapai oleh para subjek serta melakukan pengulangan pada guided imagery dan self-talk dengan tujuan untuk mengembangkan keyakinan yang lebih rasional (Eford, 2016).

Penurunan kecemasan kedua subjek tidak hanya dilihat dari hasil skor kecemasan, namun dari hasil wawancara (follow-up). Subjek A merasakan efek yang positif dari terapi ini yaitu kegelisahan pada rasa sakit menjelang menstruasi dapat berkurang dengan mengatur pola makan dan olahraga, rasa takut dan kekhawatiran klien pada sakit kistanya dapat diatasi dengan rutin untuk melakukan pengobatan serta dapat berpikir rasional dalam setiap peristiwa. Hal ini juga berdampak pada subjek A yang mendapatkan pekerjaan yang diharapkan. Begitu juga dengan subjek $\mathrm{M}$ yang merasa bahwa dirinya menjadi jauh lebih rasional dalam bertindak sehingga perasaan sedih, takut dan khawatir tidak menguasai diri subjek. Hal ini juga berdampak pada kondisi fisik yang biasanya seringkali mengalami sulit tidur, jantung sering berdebar-debar, pusing menjadi jauh lebih berkurang. Menurut peale (2009), individu yang memiliki keyakinan positif atau rasional akan melihat suatu kejadian didasarkan pada fakta bahwa setiap masalah pasti ada pemecahan dan suatu pemecahan yang tepat selalu melalui proses intelektual yang sehat. Hal ini menjadi penyebab menurunnya kecemasan pada kedua subjek.

Terbuktinya hasil hipotesis ini senada dengan hasil penelitian dari Rianti dan Dharmawan (2018) bahwa Rational Emotive Behavior Therapy dapat menurunkan kecemasan orang tua terkait 
masa depan anak retardasi mental. Hasil penelitian ini adalah adanya perbedaan penurunan kecemasan dari kategori sedang menjadi kategori ringan yaitu orang tua menjadi lebih tenang dalam menyikapi masa depan anak yang memiliki retardasi mental. Artinya, orang tua yang mengembangkan pola pikir rasional dapat meminimalisasi kecemasan pada orang tua. Selanjutnya, penelitian dari Faizah (2018) mengungkapkan juga bahwa Rational Emotive Behavior Therapy memberikan dampak penurunan kecemasan pada penderita ekstrapiramidal sindrom mahasiswa UIN Sunan Ampel Surabaya serta penelitian dari (Thahir \& Dede, 2016) menjelaskan bahwa Rational Emotive Behavior Therapy dapat mengurangi kecemasan pada peserta didik Kelas VIII SMP Gajah Mada Bandar Lampung. Hal ini menunjukkan kedua penelitian tersebut dengan adanya keyakinan irasional diubah menjadi rasional berdampak pada penurunan kecemasan.

\section{Kesimpulan dan Saran}

Hasil kesimpulan dari penelitian ini menunjukkan bahwa Rational Emotive Behavior Therapy terbukti efektif dalam menurunkan kecemasan pada dua subjek penderita kista ovarium. Hal ini diketahui dari perubahan skor yang didapatkan sebelum dan sesudah pelatihan dilaksanakan. Selain itu, melalui wawancara dengan kedua subjek yang menyatakan bahwa pikiran kedua subjek berubah menjadi rasional.

Penelitian ini memberikan masukan bagi para subjek untuk selalu mempraktikkan dan menerapkan materi yang telah diberikan dan dipelajari pada pemberian terapi rational emotive behavior therapy. Selan itu, diharapkan peserta untuk meningkatkan kemampuannya untuk mengenal, mengubah dan menyangkal pemikiran irasional menjadi rasional. Dimaksudkan bagi subjek mewaspadai timbulnya emosi negatif yang dapat menimbulkan rasa cemas kembali. Di samping itu, diharapkan para subjek untuk selalu pola hidup yang sehat serta rutin untuk kontrol ke dokter spesialis obsgyn untuk meminimalisasi resiko penyakit lainnya.

Penelitian mengenai rational emotive behavior therapy terbukti cukup efektif untuk digunakan pada individu atau kelompok yang memiliki pola pikir irasional dengan berbagai macam penyakit kronis lainnya. Selain itu, bagi peneliti yang menggunakan pelatihan ini perlu untuk memperhatikan waktu pelatihan yang memadai bagi para subjek serta penyediaan tempat agar rational emotive behavior therapy bisa berjalan dengan kondusif.

Peneliti selanjutnya disarankan untuk menambah jumlah subjek penelitian agar memudahkan proses analisis data dan memiliki hasil data yang lebih bervariatif. Selain itu, diharapkan untuk mencermati dan memberikan modul rational emotive behavior therapy yang lebih menarik dan disesuaikan dengan subjek.

\section{Daftar Pustaka}

Amita, N. (2016). Pelatihan Coping Religius dalam Menurunkan Kecemasan pada Penderita Kista Ovarium. Tesis. Yogyakarta : Universitas Islam Indonesia.

Apriani S, Hiswan \& Rasmaliah. 2015. Karakteristik Penderita Kista Ovarium pada Wanita Sebelum Menopause yang Dirawat Inap di RS. Haji Medan Tahun 2014-2015. Universitas Sumatera Utara. http://repository.usu.ac.id/handle/123456789/60328

Arismawati. (2016). Hubungan antara Pemaafan (Forgiveness) dengan Kecemasan (Anxiety) Pada Remaja yang Orangtuanya Bercerai. Universitas Pendidikan Indonesia. 
Atkinson, R.L, Atkinson, R.C., \& Hilgrad, E.R.. (2009). Pengantar Psikologi. Jakarta:Erlangga.

Berhandus,C., Loho, M.F., \& Wantania, J.J.E. (2012). Kasus terbanyak pada penyakit Ginekologi. Diakses dari download.portalgaruda.org.

Biljan,M.M., Lapense,L., Manhutte, N.G., Bissonnette, F., Hemmings, R., Lin Tan, S. (2000). Effect of Functional Ovarian Cysts Detectedon the $7^{\text {th }}$ day of gonadotropin-releasinghormone analog administration on the outcome of IVF Treatnent. Journal of Fertility And Sterility. 74(5). 941945. DOI https://doi.org/10.1016/S0015-0282(00)01555-7

Buchanan, D., Milroy, R., Baker, L., Thompson, A.M \& Levack, P.A. (2010). Perception of Anxiety in Lung Cancer Patient and Their Support Network. Support Care Cancer, 18, 29-36. DOI: $\underline{10.1007 / s 00520-009-0626-2}$

Irawati, D., Subandi \& Kumolohohadi, R. (2011). Terapi Kognitif Religius untuk Menurunkan Kecemasan Terhadap Kematian Pada Penderita HIV/AIDS. Jurnal Intervensi Psikologi, 3(2), hal 169-186. https://doi.org/10.20885/intervensipsikologi.vol3.iss2.art2

Depkes, RI. (2011). Rencana Strategis Kementrian Kesehatan 2010-2014. Jakarta. https://www.slideshare.net/adeblonde/renstra-kemenkes-20102014

Dinas Kesehatan Provinsi Jawa Tengah, (2015). Kista Ovarium artikel perbandingan di dunia kesehatan. Di akses 10 September 2020.

Dryden, W. (2009). Rational Emotive Behaviour Therapy: Distinctive Features. New York: Routledge.

Erford, B.T. (2016). 40 Teknik yang Harus Diketahui Setiap Konselor. Yogyakarta : Pustaka Pelajar.

Ellis, A. (2006). Overcoming Resistance: A Rational Emotive Behaviour Therapy Integrated Approach Second Edition. New York: Springer Publishing Company, LLC.

Faizah, N. (2018). Rational Emotive Behavior Therapy (REBT) dalam Menangani Kecemasan Penderita Ekstrapiramidal Sindrom Mahasiswa UIN Sunan Ampel Surabaya. Jurnal Transformatif 2(1), 4769. http://e-journal.iain-palangkaraya.ac.id/index.php/TF

Greenberg. L.S. (2002). Emotion-focused therapy: Coaching clients to work through their feelings. APA: Washington DC

Imade. (2013). Blogdokter Imade C. Wirawan. Jakarta : Naura Books.

Kartono, K. (2001). Gangguan-gangguan Psikis. Bandung : Mandar Maju.

Lely. (2013). Tingkat Pengetahuan Wanita USia Subur Tentang Kista Ovarium di Desa Jabung Sragen. Surakarta : Stikes Kusuma Husada Surakarta.

Nelson-Jones, R. (2011). Theory and Practice of Counseling and Therapy. Terjemahan Helly Prajitno \& Sri Mulyantini. Jakarta : Pustaka Pelajar.

Ormrod, J.E. (2004). Human learning (4th ed.). New Jersey: Pearson Education, Inc. 
Efektivitas Rational Emotive Behaviour Therapy Untuk Menurunkan Kecemasan Wanita yang Menderita Kista Ovarium Proyeksi, Vol. 16 (1) 2021, 1-14

Peale,N.V. (2009). The Power of Positive Thinking. Yogyakarta : Ragam Media.

Pearson, J. (2000). Develop the Habit of Healthy Self-Talk. Diambil dari http://www.healthyhabits.com/se;ftalk.asp

Putri, M. (2012). Penggunaan Intervensi Cognitive Behavioural Therapy (CBT) untuk menurunkan kecemasan pada Lansia. Tesis. Jakarta : Universitas Indonesia.

Rianti, V \& Ike, F.B. (2018). Efektifitas REBT Mengatasi Kecemasan Orang Tua Terhadap Masa Depan Anak Retardasi Mental. Jurnal RAP UNP. 9(2), 195-204. https://doi.org/10.24036/rapun.v9i2.102215

Seligmen,L., \& Reichenberg, L.R. (2013). Theories of Counseling and Psychotherapy: Systems, TSrategies, and skill of ounseling and Psychotherapy (Edisi ke-4). Upper Saddle River, NJ : Pearson Merrill.

Siburian, E., Karyono \& Dian, V.S.K. (2010). Pengaruh Rational Emotive Behavioral Therapy (REBT) dalam Menurunkan Kecemasan Menghadapi Masa Depan pada Penyalahguna NAPZA di Panti Rehabilitasi. Jurnal Psikologi Undip 7(1), 40-49. https://doi.org/10.14710/ipu.7.1.40-49

Sunanto, J. (2005). Pengantar Penelitian Dengan Subyek Tunggal. Criced: University Of Tsukuba

Sungkar. (2015). Dermakologi Praktis. Jakarta : Hipokrates

Susanti \& Anugerah I.S. (2017). Potensi Sirsak (Annona Muricata) Sebagai Pencegahan Kista Ovarium. $\begin{array}{lll}\text { Jurnal } \quad \text { Majority, } & \text { 6(2), }\end{array}$ https://juke.kedokteran.unila.ac.id/index.php/majority/article/view/1004

Sugiyono, D. 2(010). Metode penelitian kuantitatif kualitatif dan R\&D. Penerbit Alfabeta.

Taylor, S.E. (2003). Health Psychology. Fifth Edition. United States of America: Mc Graw-Hill, Inc.

Thahir, A \& Dede, R. (2016). Pengaruh Konseling Rational Emotive Behavior Therapy dalammengurangi Kecemasan Peserta Didik Kelas VIII SMP Gajah Mada Bandar Lampung. Konseli : Jurnal Bimbingan dan Konseling 3(2), 197-2016.

Videbeck, S.L. (2008). Psychiatric Mental Helath Nursing. USA : Lippincot \& Wilkins.

Winarti, Oktaviana, M \& Prasetya, L. (2017). Gambaran Pengetahuan Remaja Putri Kelas XI Tentang Kista Ovarium di SMK YPKK 2 Sleman Yogyakarta. Naskah Publikasi Kebidanan Universitas Alma-Ata Yogyakarta. http://elibrary.almaata.ac.id/764/1/NASKAH\%2OPUBLIKASI.pdf

World Health Organization. (2020). Profil Data Kesehatan Penyakit Kista. https://www.cancer.org/research/cancer-facts-statistics/all-cancer-facts-figures/cancerfacts-figures-2020.html 